\title{
BJRM
}

Bongaya Journal of Research in Management Volume 3 Nomor 2. Hal 07-13 Tahun 2020. e-ISSN: 2615-8868

Homepage: https://ojs.stiem-bongaya.ac.id/index.php/BJRM

\section{PENGARUH PERSEPSI DAN PENGETAHUAN KONSUMEN TERHADAP ECOLABELLING PADA KEPUTUSAN PEMBELIAN GREEN PRODUCT}

\section{INFLUENCE OF CONSUMER PERCEPTION AND KNOWLEDGE OF ECOLABELLING ON DECISION OF BUYING GREEN PRODUCT}

\author{
Ermin Lestiani $^{1}$, Siti Maryam ${ }^{2}$, Rochmi Widayanti $^{3}$ \\ Universitas Islam Batik Surakarta, Indonesia \\ e-mail : erminlestiani@gmail.com
}

\begin{abstract}
(Diterima: 19 November 2020; direvisi: 28 November 2020; dipublikasikan: 07 Desember 2020 )
\end{abstract}
(C)2018 -Bongaya Journal for Research in Management STIEM Bongaya. Ini adalah artikel dengan akses terbuka dibawah licenci CC BY-NC-4.0 (https://creativecommons.org/licenses/by-nc/4.0/ ).

\begin{abstract}
This research to analyze the perceptions and knowledge of consumers against ecolabelling and its influence on the buying decision green product (Tissue Tessa) in the city of Solo. The variable in this study the perception of the consumer $(X 1)$, knowledge (X $2)$, and consumer purchasing decisions of consumers $(Y)$. The population in this study the whole consumer Tissue Tessa in the Solo. Then the sample in this research captured 105 people or purposive sampling technique with respondents. Collection is done by giving a list of statements given to the 105 respondents who bought Tissue Tessa. Type of this research is quantitative descriptive, where its primary purpose is to describe the presence of the influence of green product against purchasing decisions.The research of using multiple linear regression analysis to analyze how the influence of green product ( Tissue Tessa) against the decision of the purchase of tissue products tessa. Based on the results of this research show that the consumer perception of the variables $(X 1)$, and knowledge $(x 2)$ the consumer is positive and significant effect of either simultaneous or partially towards purchasing decisions $(Y)$ on Tissue Tessa.
\end{abstract}

\section{Keywords: Consumer Perceptions; Knowledge; Consumer Purchase Decision}

\begin{abstract}
Abstrak : Penelitian ini bertujuan untuk menganalisis persepsi dan pengetahuan konsumen terhadap ecolabelling serta pengaruhnya terhadap keputusan pembelian green product ( Tissue Tessa) di Kota Solo. Variabel dalam penelitian ini adalah persepsi konsumen (X1), pengetahuan (X2), dan keputusan pembelian konsumen (Y). Populasi dalam penelitian ini adalah seluruh konsumen tisu Tessa di Kota Solo. Kemudian sampel dalam penelitian ini berjumlah 105 orang atau dengan teknik purposive sampling dengan responden. Pengumpulan dilakukan dengan memberikan daftar pernyataan yang diberikan kepada 105 responden yang membeli tisu Tessa. Jenis penelitian ini adalah deskriptif kuantitatif, dimana tujuan utamanya adalah untuk mendeskripsikan adanya pengaruh green product terhadap keputusan pembelian. Penelitian ini menggunakan analisis regresi linier berganda untuk menganalisis bagaimana pengaruh green product ( Tissue Tessa) terhadap keputusan pembelian produk Tissue Tessa. Berdasarkan hasil penelitian menunjukkan bahwa variabel persepsi konsumen (X1), dan pengetahuan (X2) konsumen berpengaruh positif dan signifikan baik secara simultan maupun parsial terhadap keputusan pembelian (Y) pada tisu Tessa.
\end{abstract}

Kata kunci: Persepsi Konsumen; Pengetahuan; Keputusan Pembelian Konsumen 


\section{PENDAHULUAN}

Lingkungan merupakan tempat sangat penting dalam pertumbuhan dan kelangsungan semua makhluk hidup. Kurangnya kesadaran masyarakat menjaga kelestarian lingkungan dapat mengakibatkan berbagai kerusakan dan penurunan kualitas pada lingkungan. Salah satunya adalah berkurangnya lahan hutan atau tanaman hijau yang disebabkan dari pembangunan dan penebangan oleh oknumoknum tidak bertanggung jawab. Berbagai isu lingkungan sangat mengancam kehidupan manusia, mulai dari isu sampah buangan dari pabrik, kemasan product, proses daur ulang lama serta penggunaan yang berlebihan terhadap energi serta sumber daya alam. (Santoso dan Fitriyani, 2016) Green product atau lebih dikenal menggunakan istilah ecological product atau environmental friendly product yaitu produk yang komponennya bersifatmaman, tidak beracun, mudah di reuse atau recycle, serta kemasannya bersifat ramah lingkungan guna mengurangi dampak negatif konsumsi sebuah produk. Klaim ramah lingkungan yang tertera pada ecolabel akan membentuk persepsi serta reaksi konsumen. Kesadaran konsumen bukan hanya pemahaman, akan tetapi kemauan dan kemampuan membeli sampai mempromosikan product berbasis ramah lingkungan. Kurangnya pemahaman konsumen diduga masih terbatasnya pengetahuan konsumen terhadap istilahistilah yang terdapat pada kemasan serta tidak ada tindakan penjelasan yang memadai mengenai efek dari bahan kimia terhadap lingkungan sekitar. Pengetahuan mengenai product dijabarkan sebagai kumpulan dari berbagai macam informasi baik mengenai green product yang meliputi kategori produk, atribut ataupun fitur produk, brand, price, serta kepercayaan konsumen terhadap suatu produk. (Kadek Dewi dan Gede S ,2015)

Berdasarkan paparan yang telah diuraikan, maka dalam penelitian ini dapat dirumuskan untuk mengetahui pengaruh persepsi dan pengetahuan konsumen terhadap keputusan pembelian green product ( Tissue Tessa).

\section{a. Keputusan pembelian}

Pemahaman yang terdapat pada perilaku konsumen, memiliki banyak pengaruh yang mendasari seseorang dalam mengambil keputusan untuk membeli suatu produk. Adanya rangsangan kemudian diolah dalam diri konsumen sesuai karakteristik pribadi, sebelum akhirnya konsumen memutuskan untuk membeli suatu produk. Peter dan Olson (2009 : 162) mendefinisikan keputusan pembelian ialah proses pengintegrasian yang dikombinasikan guna mengevaluasi dua atau lebih perilaku alternatif kemudian memilih salah satu diantara pilihannya. Maka dari itu, pengambilan keputusan pembelian konsumen merupakan proses menentukan salah satu dari beberapa pilihan penyelesaian masalah dengan melakukan tindak lanjut. Setelah menentukan pilihannya konsumen dapat melakukan preview kemudian dapat menentukan attitude yang akan diambil selanjutnya.

Beberapa indikator yang dapat mendukung keputusan pembelian, yaitu (Kotler, 2007 : 222):

1. Pemrosesan suatu informasi oleh konsumen untuk mencari serta menerima masukan mengenai produk Tissue Tessa.

2. Kemantapan mengenai kualitas produk Tissue Tessa yang sangat baik akan membangun kepercayaan konsumen sehingga lebih menunjang kepuasan konsumen

3. Kebiasaan membeli produk Tissue Tessa dapat dilihat dari pengulangan yang dilakukan konsumen .

4. Merekomendasi kepada orang lain bahwa produk Tissue Tessa dapat dipercaya serta menyarankan untuk menggunakan produk tersebut.

5. Konsumen memutuskan untuk membeli produk Tissue Tessa dan mengkonsumsi produk tersebut.

Salah satu study yang dilakukan oleh Muslim dan Indriyani menunjukkan bahwa kesadaran terhadap ecolabel mempunyai hubungan positif antara pengetahuan terhadap eco-label dan minat beli konsumen. Informasi yang diberikan eco-label terbukti mempengaruhi preferensi konsumen terhadap produk, bila konsumen tersebut memiliki kepedulian tinggi terhadap lingkungan. Hal ini terjadi karena terdapat budaya yang berbeda di tiap negara.

\section{b. Green Product}

Green product sangat dikenal sebagai produk berwawasan lingkungan atau produk ramah lingkungan. Suatu produk harus memiliki keunggulan atau keunikan dari produk yang lain baik dari segi kualitas, desain, bentuk, ukuran, kemasan, 
pelayanan, garansi, dan rasa supaya bisa menarik minat konsumen untuk mencoba dan membeli produk tersebut.

Menurut Santosa et al, 2014, Produk ramah lingkungan yaitu suatu produk yang tidak merusak lingkungan, baik dalam penggunaan, produksi atau pembuangan, maupun tidak merusak lingkungan atau mengganggu keseimbangan ekologis ketika mereka dibuang. Terdapat beberapa kendala dalam penerapan green product di Indonesia, seperti:

a) Minimnya kesadaran yang dimiliki oleh produsen.

b) Keraguan pada produk yang berlabel green product.

c) Persepsi mengenai produk yang berlabel green product relatif lebih mahal

\section{c. Ecolabel}

Ekolabel atau label lingkungan dapat berbentuk pernyataan, lambang/simbol, atau grafis yang terdapat di suatu label produk atau kemasan, dalam literatur produk, dalam buletin teknik, iklan atau dalam sebuah publikasi.

Menurut Ruwani dan Simanjuntak, (2014), mengenai ekolabel yaitu suatu alat yang dikembangkan berdasarkan metode pendekatan pasar dengan tujuan untuk mempromosikan perlindungan lingkungan dan kelestarian product.

Macam-macam simbol atau logo ecolabel yang terdapat di produk Tissue Tessa:

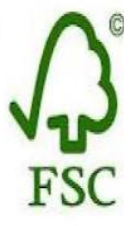

Forest Stewardship Council (FSC) adalah organisasi independen, nonpemerintah, dan nonprofit yang didirikan untuk mempromosikan manajemen hutan di dunia yang bertanggung jawab. Sertifikasi FSC menyediakan hubungan yang kredibel antara produksi yang bertanggung jawab dan konsumsi hasil hutan, memungkinkan konsumen dan pebisnis untuk membuat keputusan pembelian.

Tanda Vlegal adalah tanda yang dibubuhkan pada kayu, produk kayu atau kemasan, yang menyatakan bahwa kayu dan produk kayu telah memenuhi standar VLK yang dibuktikan dengan kepemilikan S LK.
Ecofriendly atau ecoplas adalah bahan ramah lingkungan yang mengandung $50 \%$ tepung singkong beserta sumber sumber alami lain yang dapat diperbaharui.

\section{d. Persepsi konsumen}

Persepsi sangat mempengaruhi seseorang untuk memilih salah satu produk , contohnya adalah green product, setelah mendapat informasi yang disosialisasikan mengenai isu global warming, akan membentuk tanggapan seseorang terhadap penyajian sosialisasi tersebut dan terbentuk pemahaman mengenai betapa pentingnya mengkonsumsi produk yang dapat mengurangi efek global warming, hal tersebut merupakan target pasar yang pas untuk green product (Ruwani dan Simanjuntak, (2014). Persepsi konsumen sangatlah dinamis, setiap saat mudah berubah dan perubahan tersebut dipengaruhi oleh beberapa hal yaitu kondisi ataupun situasi yang terjadi saat itu. Persepsi merupakan pokok dari suatu komunikasi, sebab jika tidak akurat, maka komunikasi tidak dapat berjalan dengan efektif. Secara singkat persepsi konsumen merupakan cara kita memandang dunia sekitar serta bagaimana mendapat informasi sebelum melakukan suatu proses pembelian.

Beberapa Indikator mengenai persepsi konsumen :

1.Persepsi memakai green product dapat berkontribusi untuk mengurangi pencemaran lingkungan.

2.Persepsi mengkonsumsi green product akan lebih menyehatkan dan aman dibanding dengan produk lainnya

3.Persepsi produk Tissue Tessa memiliki jaminan kualitas yang baik

4.Persepsi harga Tissue Tessa lebih terjangkau.

5.Persepsi konsumen tentang brand Tissue Tessa lebih unggul dikalangan masyarakat.

\section{e. Pengetahuan Konsumen}

Pengetahuan mengenai produk diartikan sebagai kumpulan dari berbagai macam informasi baik menyangkut product ramah lingkungan yang meliputi kategori 
produk, atribut ataupun fitur produk, brand, price, dan kepercayaan konsumen terhadap Tissue Tessa. Pengetahuan yang dimiliki akan sangat mempengaruhi niat beli seseorang terhadap Tissue Tessa dan juga akan mempengaruhi keputusan pembeliannya sehingga pengalaman didapat dari belajar serta akan disalurkan ke orang lain. Menurut Santosa et all, 2014, konsumen yang memiliki anggapan seberapa besar pentingnya konsekuensi lingkungan, akan membeli produk-produk yang berbasis ramah lingkungan.

Terdapat berbagai indikator mengenai keputusan pembelian:

a. Pengetahuan konsumen mengenai simbol-simbol yang tertera pada label produk Tissue Tessa.

b. Pengetahuan konsumen mengenai pernyataan yang tercantum pada label produk Tissue Tessa.

c. Pengetahuan konsumen mengenai istilahistilah yang tercantum pada label produk Tissue Tessa.

d. Pengetahuan konsumen mengenai efek negatif dari bahan kimia berbahaya yang terkandung pada bahan baku Tissue Tessa terhadap lingkungan.

\section{METODE}

Merupakan tipe penelitian deskriptif dengan pendekatan kuantitatif. Tujuan dari penelitian deskriptif ini untuk membuat deskripsi, gambaran, atau lukisan secara sistematis faktual serta akurat mengenai respon konsumen terhadap keputusan pembelian produk Tissue Tessa. Peneliti melibatkan konsumen semua kalangan pengguna Tissue Tessa pada swalayan kota Solo, seperti luwe sdan superindo. Metode pengambilan sampel menggunakan purposive sampling sebagai sumber dengan pertimbangan responden berusia 15 tahun keatas serta menggunakan teknik accidental sampling, dimana proses pengambilan sampel secara tiba-tiba bertemu.

Hair et al (2010) mengemukakan bahwa ukuran sampel yang sesuai berkisar antara 100-200 responden. Jumlah sampel minimal 5-10 kali dari jumlah indikator, yaitu (15 indikator $\times 7=105$ responden). Data primer penelitian ini meliputi karakteristik (identitas, umur, pendidikan, dan Jenis kelamin ), persepsi dan pengetahuan konsumen terhadap ecolabel serta berpengaruh pada keputusan pembelian Tissue Tessa. Pengumpulan data primer menggunakan teknik wawancara secara langsung dengan kuesioner

Berdasarkan penjabaran yang disebutkan maka dapat dirumuskan hipotesis sebagai berikut :

H1. Terdapat pengaruh persepsi dan pengetahuan konsumen terhadap keputusan pembelian Tissue Tessa sebagai green product.

H2 Terdapat pengaruh persepsi konsumen terhadap keputusan pembelian pada produk Tissue Tessa.

H3. Terdapat pengaruh tingkat pengetahuan konsumen terhadap environmental information yang terdapat pada produk Tissue Tessa sebagai green product

\section{HASIL DAN PEMBAHASAN}

\section{Karakteristik Responden}

Penyebaran kuesioner sebanyak 105 responden, didapatkan karakteristik responden berdasarkan usia, jenis kelamin dan tingkat pendidikan. Berikut dipaparkan hasil dari masing-masing karakteristik responden pengguna Tissue Tessa sebagai berikut.

1. Karakteristik responden berdasarkan usia

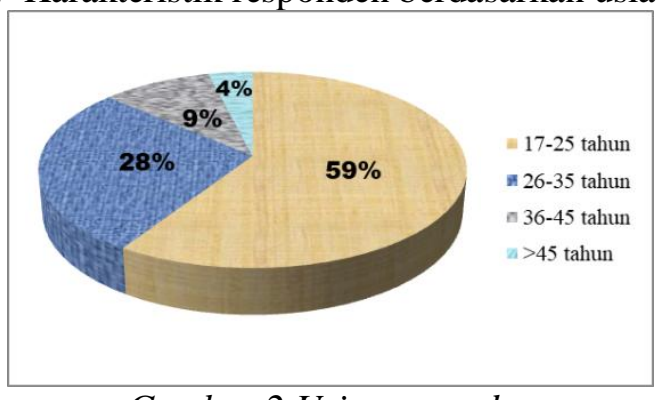

Gambar 2.Usia responden

Dapat di lihat dari hasil presentase diatas, usia responden paling banyak adalah responden dengan usia 15-25 tahun yaitu sebesar 59\%, hal ini dikarenakan tissue merupakan kebutuhan dan dianggap penting untuk dibawa saat bepergian maupun dirumah untuk kalangan usia produktif yang masih muda serta mengikuti life style sesuai pada era modern.

2. Karakteristik berdasarkan jenis kelamin 


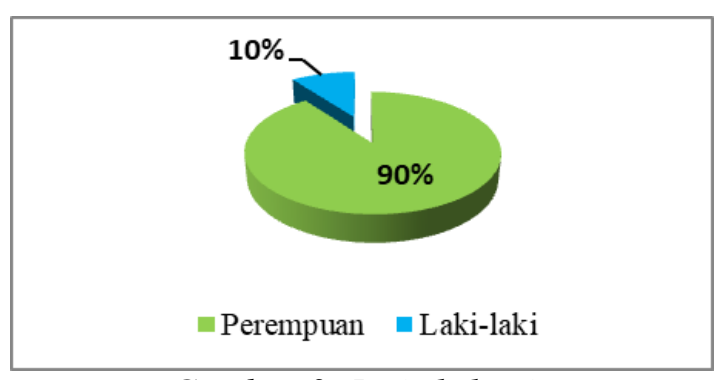

Gambar 3. Jenis kelamin

Dari presentase diatas,responden terbanyak ialah responden dengan jenis kelamin perempuan sebesar $90 \%$ dan sisanya berjenis kelamin laki-laki sebesar $10 \%$. Proporsi konsumen yang menggunakan Tissue Tessa berjenis kelamin perempuan lebih banyak dari pada laki-laki. Hal tersebut dikarenakan pada saat itu responden yang paling banyak kami temui ialah responden perempuan dibandingkan dengan laki-laki. Selain itu, responden perempuan lebih menyukai halhal yang praktis, memperhatikan kebersihan, higienis, rapi serta tissue juga identik dengan kecantikan.

3. Karakteristik responden berdasarkan tingkat pendidikan

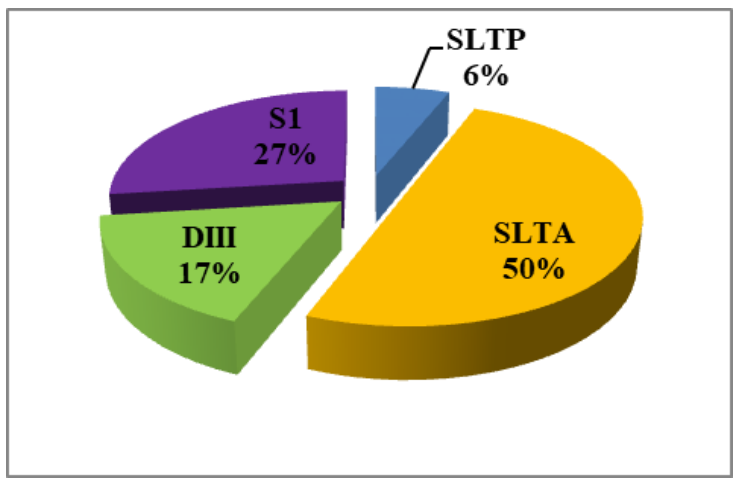

Gambar 4. Tingkat Pendidikan

Hasil penelitian memperlihatkan banyaknya responden berdasarkan tingkat pendidikan terbanyak yaitu tingkat pendidikan terakhir SLTA sebesar 50\%, terbanyak kedua ialah tingkat pendidikan sarjana (S1) sebesar 27\%. Tingkat pendidikan DIII sebesar $17 \%$, sedangkan konsumen yang memiliki tingkat pendidikan paling sedikit adalah konsumen yang berpendidikan terakhir SLTP sebesar $6 \%$. Berdasarkan hasil diatas maka dapat diketahui bahwa konsumen yang paling banyak menggunakan produk Tissue Tessa ialah konsumen yang berpendidikan terakhir SLTA hal ini dapat diketahui bahwa konsumen mulai jeli atau teliti dalam memilih produk yang aman untuk digunakan, tidak mengandung zat kimia yang berbahaya bagi kesehatan kulit serta mulai memperhatikan dampak yang ditimbulkan oleh produk bagi lingkungan.

\section{Uji Instrumen}

Uji validitas dan reliabilitas penelitian ini dibagikan 20 responden pengguna Tissue Tessa. Uji instrumen valid jika $\mathrm{r}$ hitung $>\mathrm{r}$ tabel dan nilai signifikan 5\%. Pengolahan data menggunakan SPSS versi.16 diperoleh data sebagai berikut :

\begin{tabular}{|c|c|c|c|c|c|c|}
\hline Variabel & Item & 1 hitung & If tabel & Ket & $\begin{array}{l}\text { Cronbanch } \\
\text { Alpha }\end{array}$ & Ket \\
\hline \multirow{7}{*}{$\begin{array}{l}\text { Persepsi } \\
\text { Konsumen }\end{array}$} & $\mathrm{Pkl}$ & 0,827 & 0,444 & Valid & \multirow[t]{7}{*}{0,864} & \multirow[t]{7}{*}{ Reliabel } \\
\hline & $\mathrm{Pk} 2$ & 0,79 & 0,444 & Valid & & \\
\hline & $\mathrm{Pk}^{3}$ & 0,72 & 0,444 & Valid & & \\
\hline & $\mathrm{Pl} 4$ & 0,673 & 0,444 & Valid & & \\
\hline & $\mathrm{Pk} 5$ & 0,788 & 0,444 & Valid & & \\
\hline & $\mathrm{Pk} 6$ & 0,646 & 0,444 & Valid & & \\
\hline & $\mathrm{Pk} 7$ & 0,779 & 0,444 & Valid & & \\
\hline \multirow{8}{*}{$\begin{array}{l}\text { Pengetahuan } \\
\text { Konsumen }\end{array}$} & $\mathrm{Pg} 1$ & 0,881 & 0,444 & Valid & \multirow[t]{8}{*}{0,791} & \multirow[t]{8}{*}{ Reliabel } \\
\hline & $\mathrm{Pg} 2$ & 0,681 & 0,444 & Valid & & \\
\hline & $\mathrm{Pg} 3$ & 0,775 & 0,444 & Valid & & \\
\hline & $\mathrm{Pg} 4$ & 0,053 & 0,444 & $\begin{array}{l}\text { Tidak } \\
\text { Valid }\end{array}$ & & \\
\hline & $\mathrm{Pg} 5$ & 0,668 & 0,444 & Valid & & \\
\hline & $\mathrm{Pg} 6$ & 0,569 & 0,444 & Valid & & \\
\hline & $\mathrm{Pg} 7$ & 0,619 & 0,444 & Valid & & \\
\hline & $\mathrm{Pg} 8$ & 0,745 & 0,444 & Valid & & \\
\hline \multirow{7}{*}{$\begin{array}{l}\text { Keputusan } \\
\text { Pembelian }\end{array}$} & $\mathrm{Kpl}$ & 0,689 & 0,444 & Valid & \multirow[t]{7}{*}{0,746} & \multirow[t]{7}{*}{ Reliabel } \\
\hline & $\mathrm{Kp} 2$ & 0,564 & 0,444 & Valid & & \\
\hline & $\mathrm{Kp} 3$ & 0,684 & 0,444 & Valid & & \\
\hline & $\mathrm{Kp4}$ & 0,651 & 0,444 & Valid & & \\
\hline & $\mathrm{Kp} 5$ & 0,703 & 0,444 & Valid & & \\
\hline & Kp6 & 0,591 & 0,444 & Valid & & \\
\hline & $\mathrm{Kp} 7$ & 0,58 & 0,444 & Valid & & \\
\hline
\end{tabular}

Sumber : data primer diolah tahun 2018

Hasil olah data pada tabel.1 menunjukan uji instrumen validitas semua variabel dinyatakan valid, artinya $r$ hitung $>0,444$. Kemudian hasil uji instrumen reliabilitas dinyatakan reliabel karena setiap indikator pada variabel mempunyai nilai Cronbach Alpha $>0,60$. 
Tabel. 3 Hasil Uji Regresi Linear

\begin{tabular}{|c|c|c|c|}
\hline \multirow[b]{2}{*}{ Model } & Understandart & & \\
\hline & $\mathrm{B}$ & $\mathrm{t}$ & Sig \\
\hline (Constant) & 12.095 & 6.478 & .000 \\
\hline Persepsi & .462 & 5.714 & .000 \\
\hline Pengetahuan & .144 & 2.931 & .000 \\
\hline
\end{tabular}

Sumber : data primer diolah tahun 2018

Model regresi yang diperoleh : $\mathrm{Y}=12,0+$ $0,462 \mathrm{X}_{1}+0,144 \mathrm{X}_{2}+\mathrm{e}$, dimana a (Konstan) $=12,0$ artinya jika Persepsi Konsumen $\left(\mathrm{X}_{1}\right)$, Pengetahuan Konsumen $\left(\mathrm{X}_{2}\right)$, nilainya konstan, maka keputusan pembelian Tissue Tessa bernilai $12 \%$. Koefisien $X_{1}=0,462$. Koefisien $\mathrm{X}_{1}$ bernilai positif menunjukan variabel persepsi konsumen memiliki pengaruh positif terhadap keputusan pembelian Tissue Tessa. Ditarik kesimpulan bahwa saat persepsi konsumen meningkat maka akan meningkatkan keputusan pembelian Tissue Tessa pada swalayan kota solo .

Koefisien Pengetahuan konsumen $\left(\mathrm{X}_{2}\right)=$ 0,144 . Apabila variabel pengetahuan konsumen mengenai label pada tissue meningkat maka akan meningkatkan keputusan pembelian konsumen memilih Tissue Tessa .

Tabel 4. Analisis Determinasi

\begin{tabular}{l|l|l|l}
\hline Model & $\mathrm{R}$ & R Square & $\begin{array}{l}\text { Adjuster } \\
\text { R Square }\end{array}$ \\
\hline 1 & .683 & .466 & .456 \\
\hline \multicolumn{3}{c}{ Sumber : data primer diolah tahun 2018}
\end{tabular}

Analisis data yang menggunakan alat bantu program SPSS 16.00 memperoleh nilai koefisien determinasi (Adjusted $\mathrm{R}^{2}$ ) 0,456. Artinya pengaruh yang diberikan oleh kombinasi variabel persepsi konsumen, dan pengetahuan konsumen terhadap keputusan pembelian Tissue Tessa dengan prosentase $45,6 \%$, sedangkan $54,5 \%$ dipengaruhi variabel lain yang tidak terlibat dalam penelitian.

Tabel.5 Hasil Uji f

\begin{tabular}{ll|c|c}
\multicolumn{4}{c}{ ANOVA $^{\mathbf{b}}$} \\
\hline \multicolumn{1}{c|}{ Model } & $\mathrm{f}$ & Sig. \\
\hline 1 & Regression & 44.502 & $.000^{\mathrm{a}}$ \\
Residual & & \\
\hline \multicolumn{2}{|c|}{ Total } & \multicolumn{2}{l}{} \\
\hline \multicolumn{3}{l}{ Sumber : data primer diolah tahun 2018 }
\end{tabular}

Tabel diatas menunjukan nilai $\mathrm{F}_{\text {hitung }}\left(44,502>\mathrm{F}_{\text {tabel }}(3,09)\right.$ maka ada pengaruh yang signifikan antara variabel persepsi konsumen(X1), dan pengetahuan konsumen (X2), secara simultan terhadap keputusan pembelian konsumen (Y) memilih Tissue Tessa di kota Solo.

Tabel.6 menunjukan nilai t hitung variabel persepsi konsumen senilai 5,174 dan pengetahuan konsumen senilai 2,931 secara parsial berpengaruh terhadap keputusan pembelian(Y) Tissue Tessa diketahui nilai $t_{\text {hitung }}$ lebih besar dari pada $t_{\text {tabel }}(1,984)$, atau dapat dilihat dari nilai signifikansi

\section{PEMBAHASAN}

Variabel persepsi konsumen mempunyai pengaruh terhadap keputusan pembelian produk Tissue Tessa di kota Solo.

Variabel persepsi konsumen memiliki pengaruh yang signifikan terhadap keputusan pembelian produk Tissue Tessa di kota Solo, Hasil analisis menunjukkan responden memperhatikan pentingnya penerapan green product baik secara kemasan maupun hasil olahan produk yang dijual. Konsumen beranggapan mengkonsumsi produk yang ramah lingkungan dapat meningkatkan persepsi positif. Oleh karena itu, selain persepsi produk berkualitas lebih baik, sehat dan aman, juga dinilai berkontribusi mengurangi jumlah sampah atau limbah yang tidak dapat didaur ulang.

Variabel pengetahuan konsumen mempunyai pengaruh terhadap keputusan pembelian produk Tissue Tessa di kota Solo.

Variabel pengetahuan konsumen berpengaruh positif dan signifikan terhadap keputusan pembelian Tissue Tessa di kota Solo. Konsumen yang memiliki tingkat kepercayaan yang besar terhadap pembelian green product akan menaruh perhatian yang besar pula terhadap penggunaan eco-label pada setiap green product. Begitu pula bagi konsumen yang memiliki pengetahuan yang baik tentang eco-label.

\section{SIMPULAN DAN SARAN}

Kesimpulan dapat ditarik dalam penelitian ini ialah variabel persepsi 
berpengaruh signifikan terhadap keputusan pembelian konsumen pada produk Tissue Tessa di kota Solo. Sebuah produk berbasis green product yang memiliki kualitas, brand maupun harga terjangkau serta tidak kalah saing dengan produk lainnya. Jika persepsi konsumen terhadap produk tinggi maka keputusan pembelian akan meningkat. Begitu pula variabel pengetahuan konsumen yang berpengaruh signifikan terhadap keputusan pembelian Tissue Tessa, meskipun sebagian konsumen tingkat pengetahuan terhadap informasi informasi lingkungan yang terdapat pada kemasan produk Tissue Tessa adalah rendah, tetapi mulai ada motivasi untuk belajar mengenai green product serta efek-efek yang akan terjadi. Adanya penanaman pengetahuan yang baik mengenai konsekuensi lingkungan dan kaitannya dengan ecolabel terbukti memberikan pengaruh yang positif terhadap keputusan pembelian konsumen.

\section{SARAN}

Perlu upaya yang lebih serius untuk meningkatkan edukasi terhadap konsumen mengenai ekolabel yang berupa makna dari pernyataan dan simbol yang tercantum pada kemasan produk Tissue Tessa, serta informasi mengenai dampak lingkungan berasal dari produk yang dibeli. Sehingga ekolabel berfungsi efektif, baik bagi produsen maupun konsumen, yaitu tidak hanya membentuk citra positif bagi brand (merek) produk maupun perusahaan dan untuk meningkatkan daya saing produk di pasar tetapi dapat mendorong untuk menjadi konsumen yang lebih bijak dan peduli terhadap lingkungan melalui pemilihan produkproduk yang lebih ramah lingkungan serta meminimalis efek dari produk yang di konsumsi.

\section{DAFTAR RUJUKAN}

Arikunto, S. (2006). Prosedur Penelitian Suatu Pendekatan Praktek. Jakarta: PT Rineka Cipta.

Asmani, J. M. (2012). Panduan Efektif Bimbingan dan Konseling di Sekolah. Jogjakarta: Diva Press

BNNP Sulawesi Selatan. (2012) (on line, diakses 28 April 2013)

Albert, C., \& Garci'a-Serrano, C. (2010). Cleaning the slate? School choice and educational outcomes in Spain. High
Educ, 559-582.

http://doi.org/10.1007/s10734-010-

9315-9

Dewi, Ni Kadek Novalia Citra dan Made Subudi. (2015). Pengaruh Kepemimpinan Transformasional Terhadap Kepuasan Kerja dan Turnover Intention Pada CV. Gita Karya Persada Denpasar. E-Jurnal Manajemen Unud, Vol.4, No.12, 2015:4219-4244

Hair, Jr et.al. (2010). Multivariate Data Analysis (7th ed). United States : Pearson

Kotler, Philip dan Keller, 2007, Manajemen Pemasaran, Jilid I, Edisi Kedua belas, PT. Indeks, Jakarta

Peter, J. Paul \& Jerry C. Olson. (2009). Consumer Behavior, Perilaku konsumen dan Strategi Pemasaran.Jilid kedua, Edisi Keempat. Terjemahan Damos Sihombing dan Peter Remy Yossi Pasla. Jakarta: Erlangga.

Ruwani, A., R, \& Simanjuntak, (2014). Nilai dan tipe konsumen rumah tangga dan kaitannya dengan perilaku pembelian produk makanan kemasan. Jurnal Ilmu Keluarga dan Konsumen

.Santoso, I., \& Fitriani, R. (2016). Green packaging, green product, green advertising, persepsi, dan minat beli konsumen. Jurnal Ilmu Keluarga \& Konsumen, 9(2), 147-158.

Wampold, B. E., \& Kivlighan, D. M. (2008). Research Design in Counseling, Third Edition. Belmont: Thomson Higher Education. 